\title{
Additional notes, corrections and sporophyte descriptions for Mesochaete (Bryopsida: Aulacomniaceae) in Australia.
}

\author{
H. P. Ramsay ${ }^{1,2, *}$, R. D. Seppelt ${ }^{2}$ and A. J. Downing ${ }^{2}$ \\ ${ }^{1}$ National Herbarium of New South Wales, Royal Botanic Garden and Domain Trust, \\ Mrs Macquaries Road, Sydney, New South Wales, 2000 \\ ${ }^{2}$ Downing Herbarium, Macquarie University, New South Wales, 2109 \\ *Author for correspondence: hpramsay@ozemail.com.au
}

\begin{abstract}
The genus Mesochaete Lindb. is known from tropical to temperate regions of the east coast of mainland Australia and Lord Howe Island. It includes two species, M. undulata Lindb. and M. taxiforme (Hampe) Watts \& Whitel. Leaf size, leaf cell dimensions and aspects of leaf cross-sectional anatomy appear to be the most reliable morphological features to distinguish the species and new information is given in support of their retention as separate species. Incorrect statements in the Flora of Australia and other Australian treatments are rectified. As there are no previous illustrations of the sporophyte of $M$. taxiforme, or descriptions of the peristome and spores of either taxon, complete illustrations of the two Mesochaete species are presented with a supplementary description of the sporophyte and, where available, SEMs of peristomes and spores. One of the taxa, $M$. taxiforme, is represented by very little fruiting material. Consequently, only one sporophyte was sacrificed for the SEM work. Morphologically, peristomes and spores of both taxa appear almost identical.
\end{abstract}

\section{Introduction}

The genus Mesochaete, formerly placed in the family Rhizogoniaceae but now in the Aulacomniaceae (Goffinet et al. 2012), occurs primarily in subtropical and warm- to cool-temperate regions of eastern Australia. The relatively large plant size and the 4-ranked, complanate leaf arrangement are characteristic features. In the coastal ranges of eastern Australia both species occur in similar damp habitats, on soil or rock.

Mesochaete taxiforme (Hampe) Watts \& Whitel. is a tropical species occurring primarily in north and centraleastern tropical Queensland with one record as far south as the Border Ranges between Queensland and New South Wales. Mesochaete undulata Lindb., the type species for the genus, has been recorded from tropical north, central and south-eastern Queensland through eastern New South Wales and south to far eastern Victoria. It is also recorded from Lord Howe Island (Ramsay 1984, Meagher 2011). The ranges of both species overlap in northern Queensland (Fig. 4A, B).

Brotherus (1904) considered the two species doubtfully distinct, synonymising M. taxiforme with $M$. undulata. In 1942, Dixon, being apparently unaware of the existence of M. taxiforme, described M. grandiretis Dixon as having much larger leaf laminal cells than M. undulata. Stone (1983), in her revision of the genus in Australia, 
reduced $M$. grandiretis to synonymy with $M$. taxiforme. The distinctions between $M$. taxiforme and $M$. undulata are the larger plant size, larger size of leaves and leaf laminal cells, and differences in the perichaetial leaves. Several statements in the descriptions of the genus and species which appear in the Flora of Australia treatment (Gilmore 2006, 2012) and in Meagher (2009) contain errors. Consequently, we include here revised descriptions of the genus and species based on Lindberg (1870), Hampe (1876), Brotherus (1904, 1924), Dixon (1942), Stone (1983) and our own observations.

\section{Clarification of Type specimens}

Historically, the typification of the genus is confused. Stone (1983) listed 2 citations, [Brotherus 1904; Dixon 1941]. There is also confusion in common on-line digital literature sources (e.g. Tropicos, AUSMOSS).

The citations from Tropicos read:

Mesochaete Lindb., Journal of the Linnean Society, Botany 11: 463. 1870.

T: Mesochaete undulata Lindb.

Mesochaete undulata Lindb., Öfversigt af Förhandlingar Kongl. Svenska Vetenskaps-Akademien 12: 70. 1870.

References: Lindberg, S. O. 1870. Contributions to British bryology. J. Linn. Soc., Bot. 11: 460-468.

The publication date for M. undulata should be 1871 (see title page of the volume). Whilst the paper indicates it was read in 1870, under Article 30.1 of the International Code of Nomenclature, "publication is not effected by communication at a public meeting, only by paper publication".

The citation from AUSMOSS reads:

Mesochaete Lindb., J. Linn. Soc., Bot. 11: 463 (1870).

Both of these citation sources are thus incorrect and the true publication year of both genus and species should be the 1870 Swedish publication, not the 1871 publication in J. Linn. Soc. Bot. 11.

\section{Discussion}

The genus Mesochaete is dioicous and the vegetative morphology of the species is outlined in Scott and Stone (1976), with a fuller description of both species in Stone (1983). The gametophytes of both have been illustrated in Stone (1983) and the two species are differentiated on size of the plants, leaf size and cell dimensions. A fertile shoot of M. undulata is illustrated in Meagher (2009).

Sporophytes have only been described and illustrated previously for M. undulata (Scott and Stone 1976; Meagher 2009) although Stone (1983) reported sporophytes for M. taxiforme in one collection [I.G.Stone 15772 (MEL-2233235)] (P. Milne pers. comm.)]. The sporophyte of $M$. taxiforme was described as having a longer seta with larger capsules similar to but more arcuate than those of $M$. undulata, but no illustration was provided.

Of the forty specimens of $M$. taxiforme recorded in the Atlas of Living Australia database [www.ala.org.au accessed May 2015] only one at MEL (see above) collected by Stone, has sporophytes. Recently, a number of $M$. taxiforme plants bearing sporophytes were located intermixed with specimens of Orthomnion elimbatum (Nog.) T.J.Kop. from North Queensland in a collection made near the top of Mt Lewis $\left(25^{\circ} 49^{\prime} \mathrm{S}, 139^{\circ} 21^{\prime} \mathrm{E}\right)$ by Ben van Zanten in 1968 [B.O.Van Zanten 681143 NSW ex GRO].

Characteristics of the genus and species were summarised by Gilmore $(2006,2012)$ in his Flora of Australia treatment, albeit with several incorrect features. Stone (1983) provided a description of the calyptra although Gilmore stated that the "calyptra was not seen". His description of the peristome of Mesochaete is misleading, particularly the peristome being described as papillose. The exostome is clearly trabeculate on the outer face and only papillose on the inner face while the endostome is smooth. However in the generic description above it is stated that the inner surface of the exostome is "trabeculate papillose". Meagher (2009), in his discussion of M. undulata in Victoria: stated incorrectly "Peristome single, comprising 16 long, narrow, incurved teeth". However, as the exostome appears to be rather fragile and easily broken, the peristome could appear to be single.

In both species, spores are of similar ornamentation and size. Gilmore's $(2006,2012)$ description of the spores as "smooth" is incorrect. In fact, the spores are conspicuously ornamented on the distal face with verrucose to vermicular-verruculose ornamentation (Fig. 3), but with less ornamentation on the proximal side, at least on immature spores. 
As there are no previous illustrations of the sporophyte of $M$. taxiforme, nor accurate descriptions of the peristome and spores of either taxon, illustrations of the two Mesochaete species are presented here. These include the sporophytes of both species (Figs 1,2) with a supplementary description of the sporophytes, SEMs of spores (Fig. 3). Comparative morphological characteristics of the two species are summarised in Table 1.

Brotherus (1904) considered the two species doubtfully distinct. Stem length varies considerably in both species due to environmental influences. In the fertile specimens examined, the seta of $M$. taxiforme is slightly longer, but we do not consider variation in seta length as significant and not a definitive feature. No significant differences in capsule size or shape between the two recognised taxa were observed. The peristomes are also virtually identical with only subtle differences in spore ornamentation and no significant differences in spore size.

In the absence of sporophytes, differences in leaf size and leaf cell size, sectional anatomy of the leaf border, and costal structure appear to be reliable distinguishing features. Other useful differentiating features include: (1) perichaetial leaves, larger with the apex acuminate and coarsely dentate in M. undulata (Fig. 1); smaller, with the apex long, setaceous and twisted in M. taxiforme (Fig. 2); (2) the number of cells in the width and depth in transverse section of the leaf border (Table 1); (3) costal structure, particularly the juxtacostal cells; (4) stem sectional anatomy, specifically the number of rows of outer cortical cells; (5) colour and general appearance when dry.

David Meagher (pers. comm.) has carried out preliminary molecular analyses in Mesochaete based on chloroplast loci. The results provide evidence supporting the distinctness of these two taxa. Additional molecular studies and chromosome data for M. taxiforme [ $\mathrm{n}=10$ in M. undulata; Ramsay 1974] to check for possible polyploidy could be useful.

Mesochaete Lindb., Oefvers. Forh. Kongl. Svenska Vetensk.-Akad. 12: 70. 1870.

Type: Mesochaete undulata Lindb.

Dioicous. Plants large, 4-8(-14) $\mathrm{cm}$ in length, shoots 3-10 mm wide including leaves, often forming small or spreading clumps, yellow-green to dark green, shoots complanate with closely imbricate leaves. Stems stiff, simple or with occasional short branches, reddish-black in the lower parts, becoming paler above, somewhat tomentose at the base; sometimes producing rhizoids and becoming attached at shoot apex; in section with a well-developed central strand. Leaves in 4 rows, oblong-ovate, \pm crisped when dry, asymmetrical, with a prominent marginal border of several layers of narrow elongate cells, margins undulate, denticulate above with single multicellular teeth; apical leaves often deciduous; costa strong, dividing the leaf longitudinally into two unequal halves, wider in the base and gradually tapering to the apex, shortly excurrent, merging with marginal teeth to form a toothed, cuspidate apex; in transverse section with 2 rows of median deuter cells, adaxial and abaxial stereid bands, an outer adaxial and abaxial layer of thinner-walled cells. Lamina cells small, isodiametric, irregularly hexagonal to quadrate or wider than long, those in the base slightly longer. Axillary hairs 2-4 cells long. Perigonia gemmiform, borne in axils of leaves on male shoots. Perichaetia sessile in axils of leaves in mid-region of female shoots. Perichaetial leaves all similar in size, much smaller than stem leaves, triangular-lanceolate, bordered with marginal teeth; costa strong, percurrent or ending below, or in, the apex. Setae dark red-brown below, paler above. Capsules elongate, strongly grooved when mature, almost straight to curved, suberect to almost horizontal. Operculum short-conic with a rounded apex. Calyptrae readily lost from young sporophytes, narrow, tubular, slightly curved, tapering gradually to the tip, entire at the base. Peristome double: exostome trabeculate on outer surface, trabeculate-papillose on the inner surface; endostome about equal in height to exostome, smooth. Spores small, distal surface vermicular-verruculose to verrucose, $8-12 \mu \mathrm{m}$ in diameter.

\section{Key: the two taxa may be separated as follows:}

Mid-stem leaves $2.5-4.5 \mathrm{~mm}$ long; laminal cells $10-13 \mu \mathrm{m}$; marginal border 3-5 cells wide, 2-3 cells thick; juxtacostal cells not differentiated; perichaetial leaves c. $1 / 2$ length of stem leaves, apex acuminate M. undulata

Mid-stem leaves 3.3-8.5mm long; laminal cells $20-25 \mu \mathrm{m}$; marginal border 5-10 cells wide, 4-6 cells thick; juxtacostal cells differentiated; perichaetial leaves small, c. 1/5 length of stem leaves, apex long setaceous, twisted

Note: Details of specimens and localities for M. undulata and M. taxiforme, are now readily accessible from internet resources such as http://www.avh.chah.org.au or http://www.ala.org.au. In some cases, identifications may need confirmation. 
Table 1. Comparison of morphological features of Mesochaete undulata and M. taxiforme. Data from Stone (1983) and observations from present study.

\begin{tabular}{|c|c|c|}
\hline Character & M. undulata & M. taxiforme \\
\hline Appearance when dry & Leaves slightly crisped, not twisted & Leaves strongly crisped and twisted \\
\hline Stem length & $1.0-6.0 \mathrm{~cm}$ & $4.0-14.0 \mathrm{~cm}$ \\
\hline Stem outer cortex & c. 2 cells thick & $2-4$ cells thick \\
\hline Stem leaves & $2.5-4.5 \mathrm{~mm}$ long & 3.3-8.5 mm long \\
\hline Leaf laminal cells & $(8-) 10-13(-15) \mu m$ & $(15-) 20-25(-30) \mu m$ \\
\hline Costal cells & $5-8 \mu \mathrm{m}$ wide & 8-15 $\mu \mathrm{m}$ wide \\
\hline Juxtacostal cells & Not differentiated & Differentiated \\
\hline \multicolumn{3}{|l|}{ Leaf border: } \\
\hline - Surface view & $3-5$ cells wide & $5-10$ cells wide \\
\hline - Cross section & 2-3 cells deep & 4-6 cells deep \\
\hline Perigonial leaves & c. $1.5 \mathrm{~mm}$ long, apex acute & c. $2 \mathrm{~mm}$ long, apex finely acuminate twisted \\
\hline Perigonial leaf upper cells & $15-20 \times c .7 \mu \mathrm{m}$ & $45-70 \times 12-15 \mu \mathrm{m}$ \\
\hline Perigonial leaf basal cells & $30-40 \times$ c. $10 \mu \mathrm{m}$ & $45-50 \times 12-15 \mu \mathrm{m}$ \\
\hline Perichaetial leaf length & Longer (half stem leaf) & Shorter (one fifth stem leaf) \\
\hline Perichaetial leaf apex & Acuminate, coarsely dentate & Long, setaceous, twisted \\
\hline Seta length & $15-18 \mathrm{~mm}$ & $22-25 \mathrm{~mm}$ \\
\hline Capsule length & $4.8-5.5 \mathrm{~mm}$ & $5.0-6.0 \mathrm{~mm}$ \\
\hline Spore size & $8-12 \mu \mathrm{m}$ & $8-12 \mu \mathrm{m}$ \\
\hline Spore ornamentation & Verruculose to vermicular-verruculose & Verruculose to vermicular-verruculose \\
\hline
\end{tabular}

\section{Amended descriptions of Mesochaete species}

Mesochaete undulata Lindb., Öfvers Förh. Kongl. Svenska Vetensk.-Akad. 12: 70. 1870.

Type: Australia, New South Wales, New England: ? F. von Mueller date unknown. Lindberg cites type from MEL but no specimen is currently located there.

Illustrations: Brotherus (1924) Fig. 380 p. 431; Scott \& Stone (1976) plate 60 p. 323; Stone (1983), J. Bryol. 12: facing page 354, plate 1f, 355 Fig. 2 a.

Dioicous. Shoots complanate with closely imbricate leaves, to ca. $6 \mathrm{~cm}$ in length, to $\mathrm{ca} .1 \mathrm{~cm}$ wide, simple or with occasional short branches; pale to dark green; leaves \pm undulate when moist, somewhat undulate and crisped when dry. Stems in transverse section with an outer cortical region of smaller cells 1-2(-3) rows wide. Leaves $2.5-5.0 \mathrm{~mm}$ long, asymmetrically divided by costa, with a strong multi-layered marginal border of $3-5$ rows of elongate cells, $2-3$ cells thick, margins denticulate in upper half, often more so on the broader half of the lamina. Laminal cells small, isodiametric to irregularly hexagonal, mostly equidimensional, occasionally some cells oblate, mid laminal cells (8-)10-13(-15) $\mu \mathrm{m}$ long. Juxtacostal cells not differentiated. Costa shortly excurrent, in transverse section with cells of outer adaxial and abaxial layer ca. 5-8 $\mu \mathrm{m}$ wide. Perichaetial leaves 1.0-2.0 mm long, triangular-lanceolate with margins entire to weakly denticulate, innermost leaves with an ovoid sheathing base sharply contracted to an acuminate apex with the margin in the shoulder region irregularly coarsely dentate. Setae 15-30(-35) mm long. Capsules erect to inclined, cylindrical, slightly curved, 4.8-5.5 mm in length, deeply grooved when mature and dry. Operculum bluntly conic. Peristome double, 500-800 $\mu \mathrm{m}$ in length: exostome closely trabeculate on outer surface, inner surface papillose (not trabeculate papillose); endostome of equal height, smooth, with a membranous base extending about half the length, the segments keeled above. Spores 8-12 $\mu \mathrm{m}$ in diameter, verruculose to vermicular-verruculose. Chromosome number n=10 (Ramsay 1974: 316). Fig. 1.

Notes: Stone (1983) and many others have variously mis-cited the specimens from the Flecker herbarium, of which the bryophytes were sent to CANB in 1981. Such specimens can be hard to locate on AVH due to a variety of mis-interpretations. The citations for M. taxiforme are better given as "H. Flecker NQNC 1225" (CANB 362291.1), "S. Egan NQNC 1932” (BRI: AQ 0760336) and "H. Flecker NQNC 2351" (BM 001086928). This citation method seems to have been adopted by BRI, although CANB use a different system - they 
use "collector s.n." and place "CAIRNS No ${ }^{* * * " ~ i n ~ t h e ~ n o t e s ~ f i e l d . ~(S e e ~ C l a r k s o n, ~ 1990) . ~ T h e ~ c u r r e n t ~ k n o w n ~}$ distribution of M. undulata (QLD, NSW, LHI, VIC) is given in Fig. 4A.

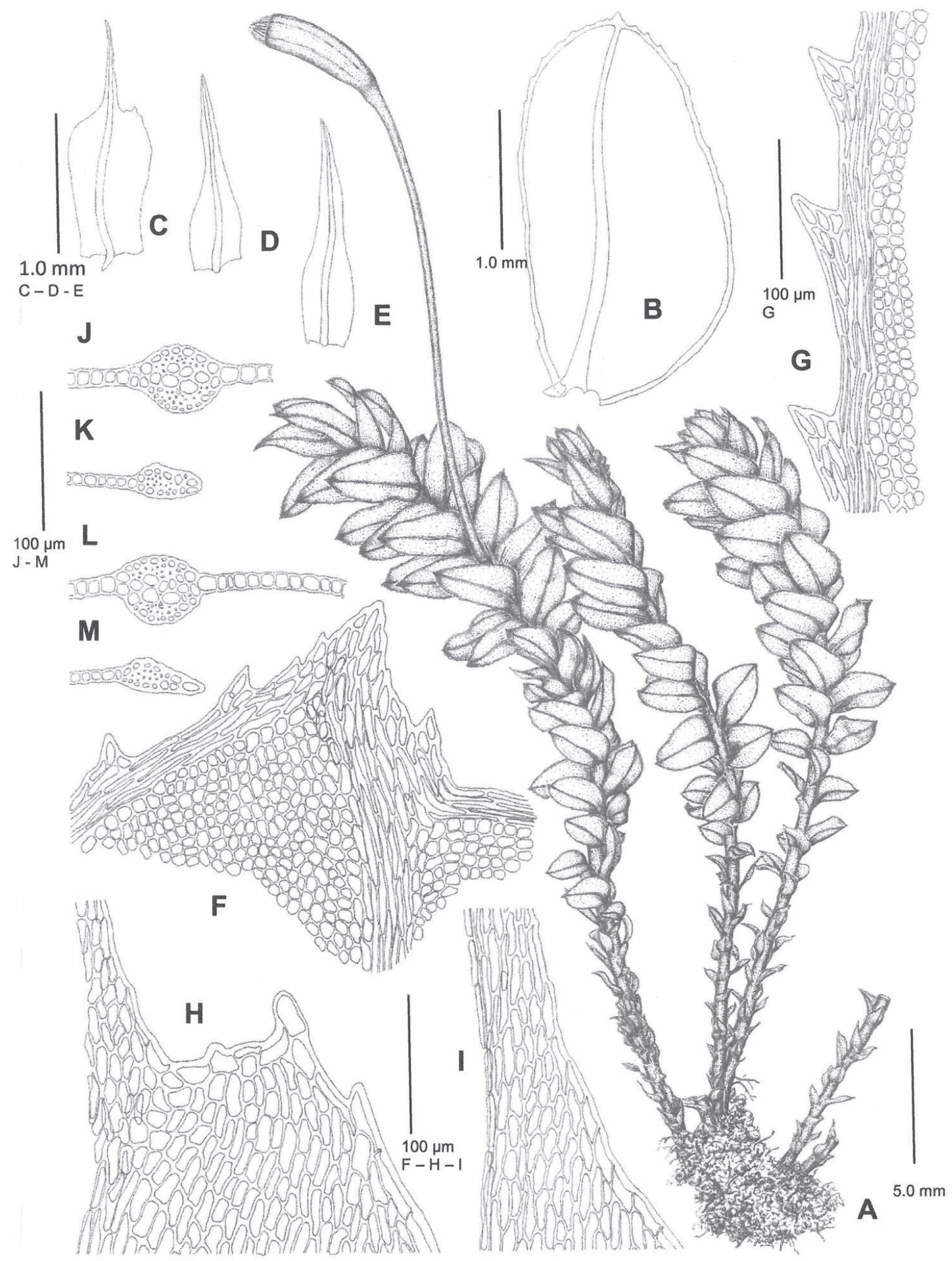

Fig. 1. Mesochaete undulata Lindb. A. Plant with sporophyte, drawn moist; B. Stem leaf; C-E. Perichaetial leaves; F. Cells of apex of stem leaf; G. Mid-lamina marginal cells of stem leaf; H. Cells of shoulder region of perichaetial leaf (C); I. Cells of shoulder region of perichaetial leaf (D); J. Costal section from mid-lamina region of stem leaf; K. Section of leaf marginal border from lamina region of stem leaf; L. Costal section from lower part of stem leaf; M. Section of leaf margin from lower part of stem leaf. Scale bars: $5 \mathrm{~mm}$ for plants (A); $1 \mathrm{~mm}$ for leaves (B-E); $100 \mu \mathrm{m}$ for leaf sections (F-M). Drawn from H.Streimann 38196 (HO-110794). Scale Bars: $5 \mathrm{~mm}$ for plants, capsules and leaves; $100 \mu \mathrm{m}$ for sections. 


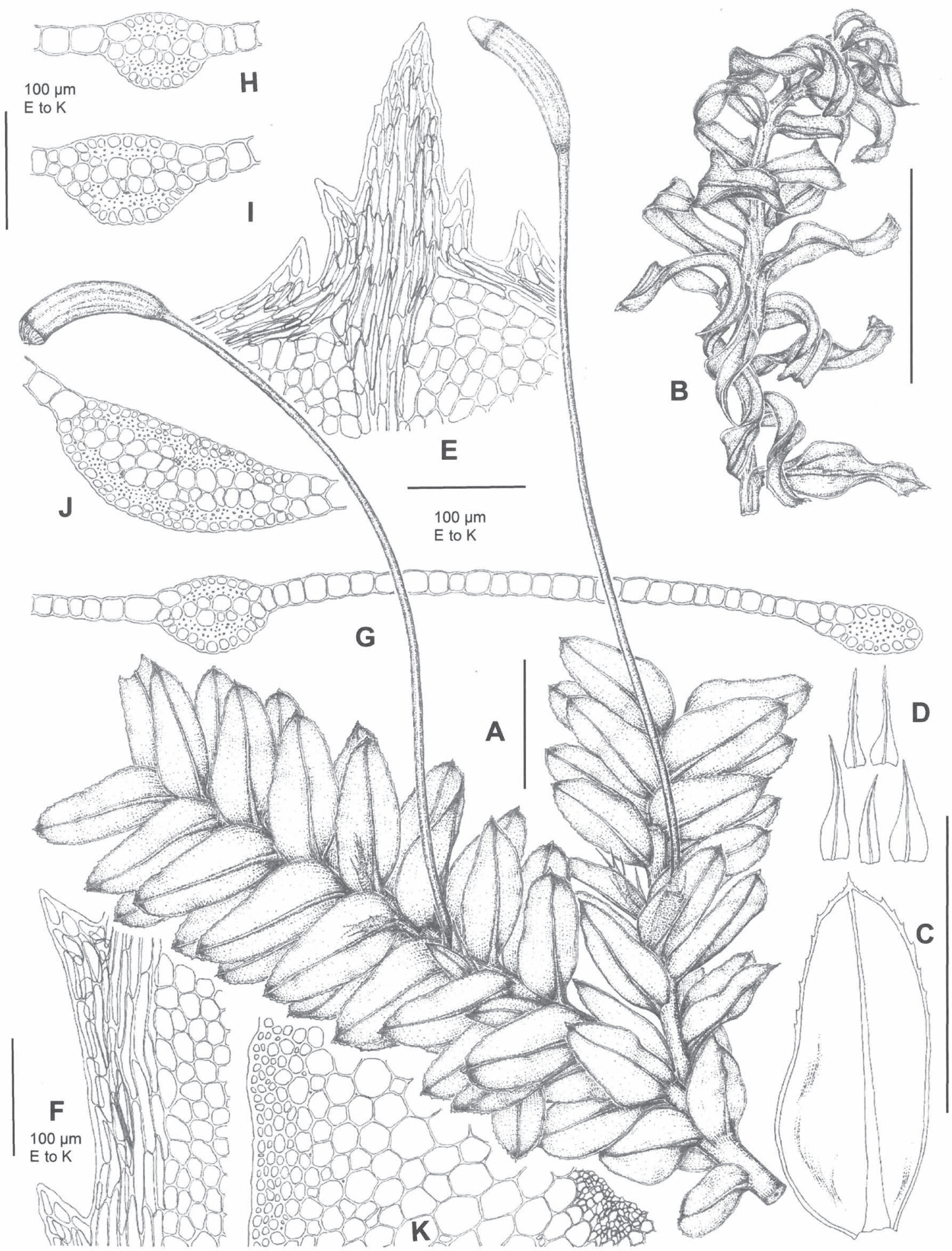

Fig. 2. Mesochaete taxiforme (Hampe) Watts \& Whitel. A. Plant with sporophyte, drawn moist; B. Shoot drawn dry; C. Mid-stem leaf; D. Perichaetial leaves; E. Cells of leaf apex; F. Mid-lamina marginal cells of stem leaf; G. Section from costa to margin at mid-leaf; H-I. Costal sections mid-leaf; J. Costal section from near leaf base; K. Part section of stem. A and D drawn from: Queensland: Mount Lewis, B.O. van Zanten 03: vii: 1968 (NSW ex GRO). B-G and J-K from L.H. Cave 521 (HO-539629). Scale Bars: $5 \mathrm{~mm}$ for plants, capsules and leaves; $100 \mu \mathrm{m}$ for sections.

Mesochaete taxiforme (Hampe) Watts \& Whitel., Proc. Linn. Soc. New South Wales 30 (Suppl.): 150. 1906.

Basionym: Rhizogonium taxiforme Hampe, Species muscorum novas ex Herbario Melbourneo Australiae. Linnaea 40: 313. 1876.

Type: Queensland: Johnstone River; W. Hill 293; Holo: BM001086926; Iso: MEL1000518A 
Mesochaete grandiretis Dixon, Proc. Roy. Soc. Queensland 53: 311942.

Type: Queensland: Platypus Creek, Cairns, H. Flecker 1225, 3 Jan 1936 Holo: BM; Iso: CANB; Baron Gorge, Kuranda, S. Egan NQNC 1932 Para: BM, BRI; Burrows Creek, Cairns, H. Flecker NQNC 1225, H. Flecker NQNC 2351 Para: BM.

Illustrations: Stone (1983) J. Bryol. 12: p. 353 Fig 1; facing p. 354 plate 1 a-e; Fig 2 i-l.

Dioicous. Shoots complanate with closely imbricate leaves, very variable in length, $3-8(-14) \mathrm{cm}$ long, $0.8-1.2 \mathrm{~cm}$ wide with leaves, simple or with scattered branches, pale to dark green, strongly undulate and crisped when dry. Stems in transverse section with an outer cortical region of smaller cells (2-)3--4 rows wide. Leaves 3.3-8.5 mm long with a strong multi-layered marginal border of elongate cells 5-10 rows wide, 4-6 cells thick, asymmetrically divided by costa; margins denticulate in upper half of lamina. Laminal cells isodiametric to irregularly hexagonal, occasionally some cells oblate, mid laminal cells (15-)20-25(-30) $\mu \mathrm{m}$ long. Juxtacostal cells differentiated, irregularly arranged, rectangular and larger than laminal cells. Costa shortly excurrent, in section cells of outer adaxial and abaxial layer ca. $8-15 \mu \mathrm{m}$ wide. Perichaetial leaves $1.0-2.8 \mathrm{~mm}$ long, triangularlanceolate with margins smooth to denticulate, innermost leaves triangular lanceolate with an acuminate denticulate apex. Setae 20-25 mm long. Capsules erect to inclined, cylindrical, slightly curved, 5.0-6.0 mm in length, deeply grooved when mature and dry. Operculum bluntly conic. Peristome double, 500-800 $\mu \mathrm{m}$ in length: exostome closely trabeculate on outer surface, inner surface trabeculate-papillose; endostome of similar height, smooth, with a basal membrane extending about half the length and the segments keeled above. Spores 8-12 $\mu \mathrm{m}$ in diameter, verruculose to vermicular-verruculose. Chromosome number unknown. Fig. 2.

Distribution: The current known distribution of M. taxiforme is shown in Fig. 4B.

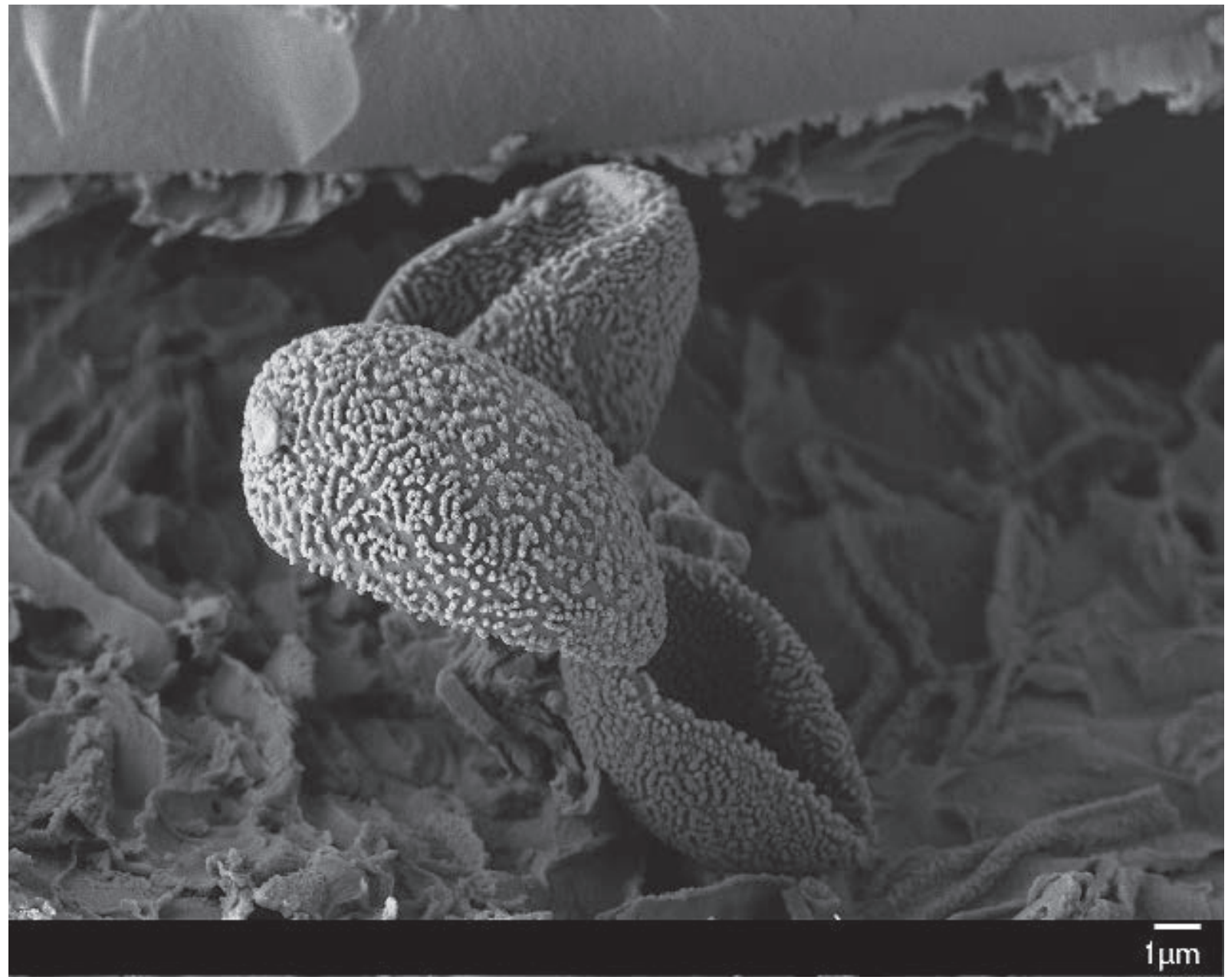

Fig. 3. Scanning electron micrograph of spores of Mesochaete taxiforme. Those of M. undulata are similar in size and ornamentation. 

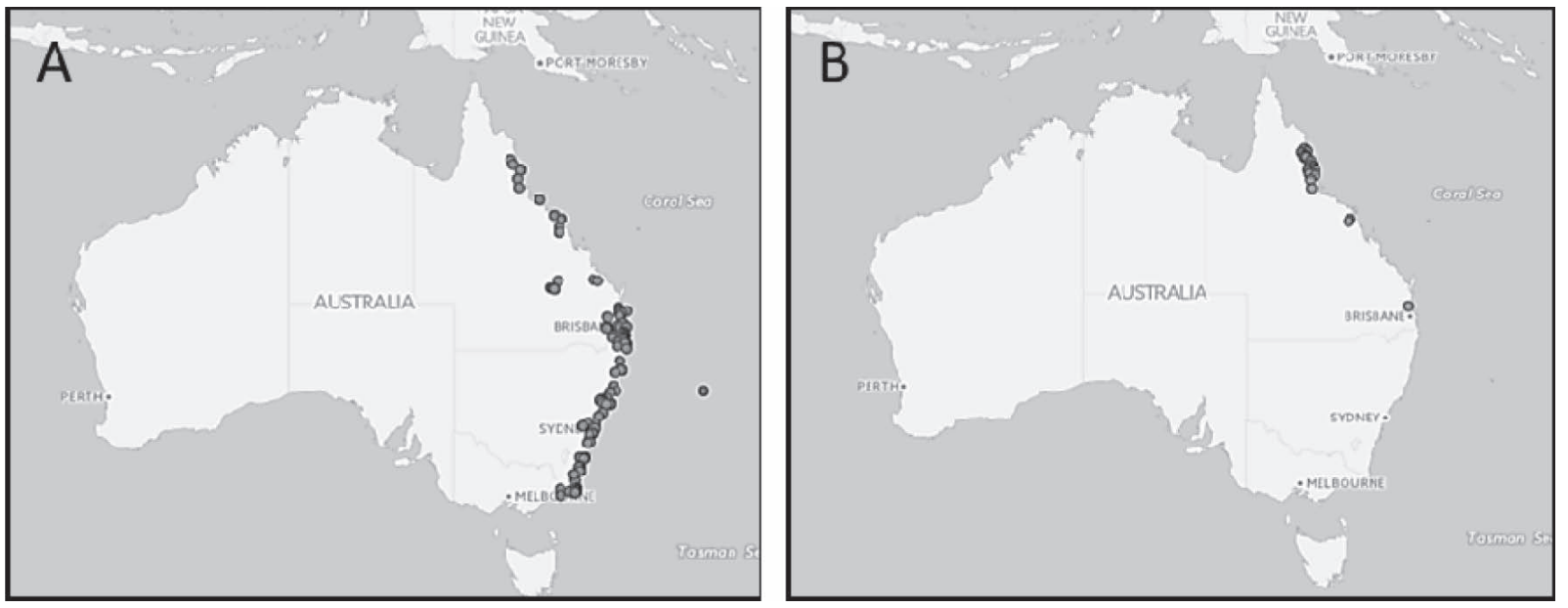

Fig. 4. Distribution of Mesochaete species in Australia: A. M. undulata; B. M. taxiforme (Data from Atlas of Living Australia).

\section{Acknowledgments}

We are most grateful to Andi Cairns for bringing to our attention some additional definitive morphological information and to David Meagher for access to unpublished molecular data enabling confirmation of the two distinct species in the genus Mesochaete. The comments of an anonymous referee who pointed out historical inaccuracies in the citation of publication dates for Mesochaete type and confusion around the citation of critical specimens from the Flecker Herbarium have helped considerably in removing some historical inaccuracies and ambiguities.

\section{References}

Atlas of living Australia (http://www.ala.org.au) accessed September 2016.

Australia’s Virtual Herbarium (http://avh.chah.org.au/) accessed September 2016.

Brotherus VF (1904) Musci. In: Engler A, Prantl, K (eds.) Die natürlichen Pflanzenfamilien. 1(3): 621. (Leipzig) Brotherus VF (1924) Musci. In: Engler A, Prantl K (eds.) Die natürlichen Pflanzenfamilien. Aufl. 2, 10: 430-431. (Leipzig)

Clarkson JR (1990) Hugo Flecker and the North Queensland Naturalists' Club. In: Short, PS (ed.) History of Systematic Botany in Australasia. (Australasian Systematic Botany Society Inc.). Pp. 171-178. (Melbourne)

Dixon HN (1942) Additions to the mosses of North Queensland. Proceedings of the Royal Society Queensland 53: 31.

Gilmore SR (2006) Flora of Australia 51: Mosses 1: 358-359. Rhizogoniaceae: Mesochaete (ABRS \& CSIRO Publishing, Canberra \& Melbourne)

Gilmore SR (2012) Australian Mosses Online 36 Rhizogoniaceae (http://www.anbg.gov.au/abrs/Mosses_ Online/Rhizogoniaceae_Mesochaete.pdf)

Goffinet, B., W.R Buck and A.J. Shaw 2012 Moss Classification at the Rank of Genus and Above. Bryophyte Biology, 2nd ed. Cambridge University Press: http://www.eeb.uconn.edu/people/goffinet/Classificationmosses.html

Hampe E (1876) Musci Novi Museu Melbournei. Continuo. Linnaea 40: 301-326.

Lindberg, S. O. 1870. Nya mossor. Öfversigt af Förhandlingar Kongliche Svenska Vetenskaps-Akademien 12: $70-84$.

Meagher D (2009) Studies on Victorian bryophytes. 10. The genus Mesochaete Lindb. Victorian Naturalist 126: $160-162$.

Meagher D (2011) Three interesting bryophyte records from Australia. Australasian Bryological Newsletter 59: $10-11$.

Ramsay HP (1974) Cytological studies of Australian Mosses. Australian Journal of Botany 22: 293-348.

Ramsay HP (1984) Mosses of Lord Howe Island. Telopea 2: 555.

Scott GAM, Stone IG (1976). The Mosses of Southern Australia. Academic Press, Cambridge

Stone IG (1983) A re-evaluation of the species of Mesochaete Lindb. (Rhizogoniaceae). Journal of Bryology. 12: 351-357. 